\title{
The Gender of Crime and the Normalization of Male Violence by the North American Justice Systems ${ }^{1}$ Cathy Marston
}

\section{INTRODUCTION}

The very concept of "being a man" has always implied that, when necessary, men can take action that breaks the law.

- hooks, 2000, p. 37.

Women who have committed violent crimes have historically been constructed as the antithesis of femininity, whereby their womanhood is challenged by their characterization as dangerous women.

- Kilty and Frigon, 2006, p. 40.

I contrast the above quotes from American, black, feminist theorist bell hooks and Canadian, feminist criminologists Jennifer Kilty and Sylvie Frigon to illustrate how in our patriarchal world, male actions are seen as inherently lawful even when they violate written laws, and how violating laws can strip a woman of her femininity to leave her branded "dangerous". This article is part of my ongoing efforts as a wrongfully-incarcerated survivor of male battering to deconstruct the ideologies and systems of oppression responsible for the above misogynist worldview and practices. My goal is to eradicate them.

I have partially situated myself above, but let me add that I am a white, doctoral-educated, feminist media scholar with 22-year-old repetitive strain injuries (RSI) in my hands, arms, neck and back dating back to the inherently injurious duties of newspaper copyediting (Marston, 1999; also see Pascarelli and Quilter, 1994). The Austin, Texas police found my abusive ex-boyfriend and his best friend trying to kill me on 13 January 2004 and found that friend on top of me grinding my face into the cement and smothering me on 13 December 2004. Both times the police arrested me, the victim, despite seeing these men trying to kill me - which is known as a "crime in view" mandating arrest under the warrantless arrest provision (chapter 14) of the Texas Code of Criminal Procedure.

The Texas Council on Family Violence reports that the Texas police have a deliberate, unique pattern of arresting battered women instead of male batterers at least 20 percent of the time on a "domestic-violence call" where this misogynist atrocity happens 3 percent of the time in other states (Marston, 2010; 2011, 2014a, 2014b). I clearly have lived the assertion 
made by hooks that men can break the law, with the support of the system that is supposed to enforce the law. Despite their knowledge and viewing of photos of extensive injuries inflicted by my battering ex and his friend, and despite admissions by the police and my batterers that the police found my batterers on top of me, the District Attorney (DA) actually characterized me as "deranged and dangerous" - while she asserted the (false) victimhood of my batterer and portrayed his friend as a hero.

\section{FEMINIST METHOD}

I position myself as a feminist researcher who had her $\mathrm{PhD}$ and a research record before her arrests. I earned my $\mathrm{PhD}$ in 2000 and was an internationally published and presented expert on repetitive strain injuries (RSI), LGBTQ and disability rights, and newsworkers (see, for example, Marston, 1999a \& 1999b). In 1998, I garnered a research award from the Association for Education in Journalism \& Mass Communication (AEJMC), the largest journalism educator association in the United States, for my preliminary, feminist, ethnographic work on college newsworkers learning work practices and work ideologies that were damaging to their bodies (Marston, 1998).

This article is a blending of feminist narrative, journalistic, and ethnographic techniques used to situate myself within my ongoing efforts to make personal and academic sense of my experiences. Feminist epistemologist Sandra Harding (1987, p. 3, original emphasis) argues that traditional epistemologies systemically "exclude the possibility that women could be 'knowers' or agents of knowledge". Feminists have, thus, proposed alternative theories of knowledge that legitimize Others as knowers, namely those who are not white, upper-class, able-bodied, heterosexual and male (ibid).

Since these categories of identity are so important to each researcher's frame of reference in research construction and method, Harding argues that the best feminist analyses, as well as the best analyses from any research perspective, should insist that the researcher be placed in the same critical plane as the subject matter so that others can decide for themselves the bias inherent in the entire research process. I have already situated myself above.

As someone trained in feminist ethnography, I studied with Laura Lein and Elizabeth Fernea at the University of Texas at Austin and Margery Wolf at the University of Iowa. I have been puzzled at the usage of the term "autoethnography", including by convict criminologists, because as a feminist, I already situate myself in my work. ${ }^{2}$ As a journalist, I 
learned nonfiction writing techniques in high school and college, then honed them with a narrative study of women journalists' experiences with and definitions of sexual harassment (Marston, 1993) and my feminist ethnography of college newsworkers (Marston, 2000). I agree with anthropologist Liz Bird (1987) and media scholar Paula S. HorvathNeimeyer (1990) that there is much shared between these methods and writing styles, as well as much that journalism and anthropology have yet to learn from each other. I argue that anthropological methods and cultural context are crucial to writing from a feminist perspective (Marston, 1996).

Ethnography is a method and a form. I endeavour to write clearly to make my work accessible, minimize jargon and so on. The bodily experience of writing this article with RSI has included musculoskeletal pain in my hands, arms, neck, and back, and eyestrain. This began as a paper typed on a typewriter in prison. It was revised on a computer at home, with use of reading/writing stands so I can stand as I work. However, upon my release from prison in July 2014, my old, voice-recognition computer from 1995 no longer worked. So, I had to key by hand at first and this journal had to get Gabrielle Pilliat, a graduate student who volunteers for the Journal of Prisoners on Prisons, to key my paper into a digital format. I wake frequently at night, unable to sleep from pain in my hands and my neck. X-rays in December 2014 revealed that I have completely lost the cervical curve (a.k.a. cervical lordosis) in my neck. As I revise in 2015, the state finally purchased a replacement computer that I am relearning voice software on.

All texts are constructed through the lens of their writers, which has been debated extensively in anthropology (i.e. Behar and Gordon, 1995; Clifford and Marcus, 1986; Wolf, 1992). Feminist anthropologist Margery Wolf (1992) believes that very few anthropologists read ethnography for their form, but instead for their content. She reminds us that as feminists, we have a responsibility not to use obscure forms, which will make our work accessible only to other academics. She goes on to say "[e]xperience is messy" and "[w]hen human behavior is the data, a tolerance for ambiguity, multiplicity, contradiction, and instability is essential" (ibid, p. 129).

As someone who loves doing research "at home", feminist sociologists Patricia Hill Collins (1986) writes that being an "outsider within" mainstream, white, male, (able-bodied, heterosexual, upper-class, academic) culture can help offer a critique of that culture. This is not an easy task. Diane Bell (1993) could not escape gender relations at home in Australia, where she 
was sexually harassed by male activists and had an article removed from a legal journal prior to publication because of her own activism.

Feminist, disability theorist Susan Wendell $(1989,1996)$ writes that the oppression of people with disabilities and of all humans based on their bodies comes from the hiding of bodily experience - which is why many often fear illness and death. She believes we need to create a "language of the body" to share bodily experiences and reduce fear and oppression. Nancy Mairs (1996, pé 60), for example, argues that she always writes consciously "as a body" and that this exiles her work "from conventional academic discourse". She calls one of her anthologies, Carnal Acts, to reveal the act of her body emerging in her writing through her life experience with multiple sclerosis (Mairs, 1990). I strive to create my own "language of the body" and agree with sociologist and media scholar Gaye Tuchman (1991, p. 92) when she feels "extended participant-observation method is for the young" because of the physical strain of long hours of observation and note-taking. I would add that this is true of any form of research, which requires a lot of sitting and writing, and I had to take that into consideration as a person with a workload disability while doing ethnography and while writing this piece.

Ideally, this article attempts to educate and prescribe solutions to my case and the cause of wrongfully-arrested battered women in Texas by contextualizing within increasing male violence, as well as police and prosecutorial collusion with it.

I will focus primarily on building my theoretical framework via a feminist literature review to weave a multiaxial analysis of white, capitalist, patriarchal violence as the natural extreme of socialization in our society. Then, I will discuss how the criminal justice system interacts with these patriarchal biases to women versus men. My hope is to review literature for a subsequent study of media coverage of recent trends of normalization of male violence in the United States, including: mass shootings (including at public schools), and military men's and football players' violence against women.

\section{FEMINIST THEORY, IDENTITY AND CRIMINALITY}

White supremacy has taught [adult, white males] that all people of color are threats irrespective of their behavior. Capitalism has taught him that, at all costs, his property can and must be protected. Patriarchy has taught him that his masculinity has to be proved by the willingness to conquer fear through aggression.

- hooks, 2000, pp. 194-195. 
In the introductory quote to this paper, hooks makes a statement about what constitutes "maleness" in the American culture, vis-à-vis the legal system. This maleness cannot be separated out from the influences of white supremacy, capitalism, and the patriarchy, as she deftly adds above: white, capitalist, and patriarchy are all identities of violence. hooks comes to this topic as a survivor of childhood abuse, using her personal history in an attempt to unpack the concept of "love" and how we can still seek it in such a world. She argues that we need to understand "the way power and privilege are accorded men simply because they are males in a patriarchal culture" (ibid, p. 37).

hooks then microanalyses men and how, as boys, they are socialized into numbing their feelings, distancing themselves from others and learning to lie. On the macro, cultural level, hooks asserts that this socialization escalates pervasive male battering and rape of women. "Love and abuse cannot coexist. Abuse and neglect are, by definition, the opposite of nurturance and care" (ibid, p. 6). She gives, as an example, the man who batters his children and wife as he passionately "proclaims he loves them" (ibid) - this is one of our culture's patriarchal lies. When my most recent batterer heard in Spring 2000 about a prior boyfriend who beat me on my $20^{\text {th }}$ birthday, he cried as he said, "Cathy, I would never hurt you. I love you". Yet the man who said that proceeded to punch, shake, choke, and verbally abuse me and injure my dog when he and I lived together in 20002001. He is the one who nearly beat me to death, breaking my foot, from about 11 p.m. on 12 January 2004 until somewhere after midnight on 13 January 2004 - then went to get his best friend to join in so that the police found both of them on top of me.

hooks explains this contradiction between the batterer's words and deeds as such: "Too many of us need to cling to definition of love that either makes abuse acceptable or at least makes it seem that whatever happens was not that bad" (ibid, p. 6). She blames "other males and sexist mothers" for teaching boys to "mask true feelings" (ibid, p. 38). Zachary Shore $(2008$, p. 38) calls this a lack of "emotional literacy" in boys; and hooks credits it with creating in boys "an inability to assume responsibility for causing pain" (ibid, p. 39). This is especially true in how men victim-blame women "in cases where men seek to justify extreme violence toward those less powerful" (ibid). 
Ellen Pence (2011) co-created "Turning Points: A Non-Violence Curriculum for Women" taught in the Batterer Intervention \& Prevention Program (BIPP) for women, such as myself, who are court-ordered via civil, protective-order cases or criminal-court, jail-diversion programs. She stated in a DVD that she has never heard a male batterer refer to his victim by name; that he Others the victim by calling her "crazy", "bitch", or some other derogatory term to dehumanize her so he can justify beating her. I have been called that and more by my batterers and I have been called worse by the prosecutors who also sought to distance themselves from my victimhood to justify false prosecution.

In a review of Margarita Pisano's, El triunfo de la masculinidad, Natalia Thompson (2012, p. 8) agrees that "masculinity" is a "super-ideology" that "has adopted patriarchy's sinister standbys such as narratives of conquest (whether on the battlefield or in bed)" to create a misogynist apparatus "more hidden and more devastating than that of old-school patriarchy". Thompson argues that "histories of colonization and recent neoliberal projects" create "una cultura del dominio" that has "dismembered women's bodies (literally and figuratively) and deformed social movements" (ibid).

Feminist, disability theory has informed my view of identity and social constructs such as "gender" and "crime" with arguments such as that of Canadian, feminist, disability theorist Susan Wendell (1989, p. 107) that "disability is socially constructed from biological reality". American, feminist, disability scholar Rosemarie Garland Thomson (1997, p. 6) agrees, adding: "disability . . . is the attribution of corporeal deviance". It is a value-judgment, as is the dualistic constructs of gender or of criminal (versus noncriminal). Wendell (1989, p. 111) argues that oppression of people with disabilities comes from able-bodied people not wanting "to know about suffering caused by the body" just as hooks argues that men do not want to know about women's suffering, or even their own emotions. Thomson (1997, p. 41) goes further to say that disability subverts the liberal, American ideal of becoming master of self: "The disabled body stands for the self-gone out of control, individualism run rampant" (ibid, p. 43).

I have argued that psychiatry was legitimized solely to create mythic, mental maladies-all social construct without biological reality to continue to oppress women after the burnings and hangings of the Inquisition/ Burning Times fell out of favour (Marston, 2011; also see Savage, 2000). Susan Faludi (1991) traces the history of the American Psychological Association pathologizing and victim-blaming female, battering survivors 
via diagnoses: first as "masochists", then as having "Battered Women's Syndrome". Meanwhile, there is no diagnosis for male batterers, of course. Unless one counts so-called "Posttraumatic Stress Disorder", which is often used to excuse the conduct of male soldiers who return home and beat and/or kill their female, significant-others. I resent any suggestion that I have some mythic, mental malady because I was beaten and nearly killed repeatedly. ${ }^{3}$

Feminist criminologists Jennifer Kilty and Sylvie Frigon (2006, p. 44) argue: "Syndromizing women's actions [Battered Women's Syndrome] may lead to an increase of the power of such psychiatric diagnoses which explain women's behaviour as disorderly rather than reasonable". A reminder that women defending ourselves via our state's self-defence statutes is our right, not the deviant behaviour the justice and media systems of patriarchal culture portray it as. Battering is the crime.

\section{WOMEN, VIOLENCE AND THE JUSTICE SYSTEM}

"[E]ven by conservative FBI statistics, if you add up all the women in the U.S. who have been murdered by their husbands or boyfriends since 11 September 2001 - and then add up all the Americans killed in 9/11 plus the wars in Iraq and Afghanistan - many more women have been killed by their husbands and boyfriends, yet we put much more thought and money into ending foreign terrorism than into ending domestic terrorism" (Steinem, 2014, p. 31). In her speech accepting the Presidential Medal of Freedom, American, white feminist Gloria Steinem reminded us that the "causes of violence" are not "distant". The above compares women's death-by-malesignificant-others with civilians and soldiers killed by "foreign terrorists" since 11 September 2001. Clearly terrorism is something American males inflict on women, in terms of policy and funding priorities.

However, the justice system does not see it that way. My experience as a wrongfully-convicted, battered-woman educated me to the fact that women are supposed to settle for less from the justice system, just as we are supposed to settle for less pay at work and the like. Regarding violent, criminal conduct against women and the language used to describe it, feminist, media scholar Marian Meyers (1994, p. 47) prefers to use the term "battering" because "terms such as... domestic violence obscure the relationship between gender and power by failing to define the perpetrators and victims". Feminist philosopher Mechthild Nagel (2013, p. 155) adds to Meyers' observations: "labeling something as 'domestic' has the ring of 'harmlessness"'. Considering the 
femicide statistics, and the fact that men batter a woman every 12 seconds here in the United States (Jones, 2003, p. 449), many men - by definition - are violent and harmful terrorists of women.

Nagel discusses the attribution of deviance and gender dating back to the 1804 Napoleonic Code, in terms of influences on our legal system, the Code relegating women to the same status as "children, felons, and the insane" (LeGates, 1995, p. 496, as cited in Nagel, 2013, p. 150). Nagel then shows the similarity between Judge William Blackstone's "Unities Doctrine" in family law informed by the white, capitalist, Christian patriarchy - and Muslim "Shar'ia law" and veiling of women. Both involve the wife being "covered" under the husband/male and being seen as chattel and "civilly dead" (Nagel, 2013, p. 150). Nagel argues that this worldview leads to an erasure of women in the public and legal spheres: a codification of our death-in-life.

If women are, at best, chattel, then: "[h]ow can somebody be castigated as violent if he couldn't do what he pleases with his property?" (ibid, p. 155). Nagel reminds us that the "rule of thumb" permitting men to beat their wives (with a stick no bigger than their thumb)" was "a compromise solution of the 'justice system' that was clearly intent on keeping the woman in a subjugated role" (ibid).

Rape is permissible under this legal worldview. As American, feminist, legal scholar Catharine Mackinnon (1989, p. 179) argues, rape "from a woman's point of view is not prohibited; it is regulated". Here, terms such as "acquaintance/date rape" are meant to imbue sexual brutality with that "harmless" air Nagel and Meyer referred to regarding "domestic". Mackinnon (1989, pp. 180-181) adds:

Many women are raped by men who know the meaning of their acts to the victims perfectly well and proceed any way. But women are also violated by men who have no idea of the meaning of their acts to the women. To them, it is sex. Therefore, to the law it is sex. ... When a rape prosecution is lost because a woman fails to prove that she did not consent, she is not considered to have been injured at all... She had sex. Sex itself cannot be an injury. Women have sex every day. Sex makes a woman a woman. Sex is what women are for. (ibid, pp. 180-181).

...From whose standpoint, and in whose interest, is a law that allows one person's conditioned unconsciousness to contraindicate another's 
violation? In conceiving a cognizable injury from the viewpoint of the reasonable rapist, the rape law affirmatively rewards men with acquittals for not comprehending women's point of view on sexual encounters (ibid, p. 182, emphasis added).

Mackinnon summarizes by arguing that normalizing sexual violence against women and making it reasonable leads to Othering women by reducing them to "their fuckability" (ibid, p. 183).

U.S. Senator John Cornyn, of Texas, stated in 2012 that there were "upwards of 400,000 DNA swabs never tested" sitting in police rape kits across the U.S. (Capitan, 2012). Ms. Reporter Stephanie Hallett (2011) also reported that there were 22,000 of those untested kits here in Texas, and that when a rape kit was tested, it often identified the DNA of a serial rapist and/ or murderers of women.

Hallett and Jeanne Clark (2007) note that male police officers are four times more likely to have active/recent charges for battering women themselves, creating some insight into why police are not prioritizing and showing due diligence to male violence against women. Ann Jones (2003, p. 452) writes that "one 1991 study found that among assaultive men arrested, prosecuted, convicted, and sentenced, less than 1 percent $(0.9 \%)$ served any jail time". Contrast that with Dr. Phil McGraw ("Dr. Phil Show") on 9 November 2011 showing a video of Aransas County, Texas Judge William Adams beating his 16-year-old daughter, Hillary, with a belt as he yelled: "I'm going to beat you into submission!" Her offense? File-sharing on the Internet. Adams response: "I was just disciplining her". Hillary's mom, Hallie, divorced Adams for battering her. Adams is a Family Law/Domestic Violence Court judge adjudicating and sentencing batterers like himself.

Of course, that is if the batterer makes it to court. Prosecutors in Topeka, Kansas, claimed their budget was so tight that they could no longer prosecute misdemeanors. So, the DA set free 18 male batterers, according to a 11 October 2011 story on NPR's "All Things Considered". A 21 May 2013 story on "All Things Considered" reported that Oregon was cutting public safety jobs to save money which meant that they were not answering 911 calls overnight and on weekends. NPR played a call to the Josephine County Sheriff's Office at 4:15 a.m. of a woman reporting that her boyfriend was trying to break into her house as she spoke! The operator stayed on the phone with her for 10 minutes. After the operator hung up, he broke into the house and was later arrested for sexually assaulting the caller. NPR quoted 
a domestic-violence expert who worried that women were staying with their batterers, because the cops were essentially saying, "If you're a woman, move somewhere else!"

Police were not interested in the drowning death of Kathleen Salvio until her husband's next (and fourth) wife disappeared. The man finally tried for Salvio's death was, of course, her husband and ex-cop Drew Peterson (Associated Press, 2012). Michigan police officer Clarence Ratliff shot to death his wife, Judge Carol Irons. He was sentenced to 15 years for murdering Irons and sentenced to two life terms for shooting at the cops, according to Ann Jones (2003, p. 453). Jones asserts that: "[i]n the scales of American justice, men weigh more that women. Assaulting a man is a serious crime, but "assaulting a woman or even killing her well, that's not so bad" (ibid). That begs the question, of course, of what happens when women have to fight back to defend ourselves.

Canadian, feminist criminologists Dianne Martin (1999) and Laureen Snider (2003) both argue that females historically were invisible to male criminologists and an afterthought in penitentiaries. In tracing the history of criminology, Snider shows that feminist criminologists had to reclaim criminalized women from male criminologists - who branded her as "inferior" and "defective" and "more terrible than any man" (Snider, 2003, p. 357, citing Lombroso and Ferrero, 1895). Snider (2003, p. 363, original emphasis) argues that "feminist criminology has constituted the fallible expert". She says that this is the most important implication of that work: "Destabilizing the cult of expertise has been significant in constituting the resistant female offender, providing her with the languages and the legitimacy to dispute the truth claims made about her" (ibid). Women have been over-represented in sex-specific crimes such as abortion, infanticide, and prostitution. Criminalized and incarcerated women were an afterthought in penitentiaries, which were conceived for male prisoners (ibid, p. 357).

In looking at modern punishment of the criminalized woman, Snider examines only leading English-language schools of feminist criminology. She finds that large-scale, quantitative research is more commonly used in the United States. Qualitative, ethnographic studies are more often found outside the United States, particularly in Canada, Australia, and the United Kingdom (ibid, p. 362). The theoretical questions involve two main themes. First, there's "the generalizability question: "...[C]an male(stream) theories of crime be extended to cover female criminals?" The other theme is what 
she calls "the gender ratio issue-why do so few women, relative to men, commit crimes?" (ibid). Snider finds a great pervasiveness of gender bias still in research, "masquerading as gender neutrality and hidden under the guise of science", meaning that "women, if present at all, are still 'at best a complicating figure - in the male story of crime"" (ibid). Crime is judged differently, as well:

...rebellion by male subjects is romantic independence, in females it indicates pathology or promiscuousness; legal conformity by males indicates a well adjusted, appropriately bonded individual, legal conformity in women indicates their passivity, lack of independence, or 'over-socialization.' (ibid, pp. 362-363)

Martin (1999, p. 186) analyzes the sentencing and confinement of female "offenders", arguing that they have been overlooked by the criminal-justice system because they represent a small minority of persons charged or convicted. Martin argues that "[c] rime is a masculine occupation. Women are the exception in criminal courts-whether as judges, lawyers, police officers, victims, witnesses, or accused" (ibid, p. 187). Like Snider, Martin claims that women are often treated as anomalies, with consequences:

Sometimes the experiences unique to women are ignored in the name of judicial neutrality, and matters such as pressures from family violence, which should be considered are ignored. At other times, the simple fact of gender is acknowledged as if relevant in itself, and that acknowledgment produces unintended harms by perpetuating stereotypes and reinforcing biases. The identification of difference can also produce overtly harsh sentences (ibid).

Martin says that sentences "intended to deter or reform the male offender too often simply crush or brutalize a woman" (ibid, p. 188).

In studies in the area of gender-ratio, girls were found to receive longer sentences for sexual acting-out that was ignored or admired in boys (Chesney-Lind, 1981, 1987, 1988). Moreover, black and aboriginal women never received less than the mandated quota of punishment (and often got longer sentences served in harsher conditions) (Kruttschnitt, 1981; Spohn et al., 1987). The result, in policy terms, has been ever higher rates of 
incarceration for women and girls, "equality with a vengeance" (Snider, 2003, p. 363). Snider summarizes with two points:

First, it is significant that lenience arguments were only, ever always heard as arguments for increasing the punishment of women, never for infusing mercy into the treatment of men. Punishing up, not "leniencing down;" equal opportunity oppression not equal opportunity clemency. ... Second the institutional sites where women were subjected to more intensive surveillance, discipline, and punishment than men, many of them outside criminal justice venues, were never deemed problematic (ibid).

She says that women are more likely than their male counterparts to serve time in a locale many kilometers away from friends and family. Fewer job training and educational programs will be available to her, and she will be housed in inferior conditions at excessive security levels (ibid, p. 365). Snider then reports the only way women prisoners are better off than men: "incarcerated women appear far less likely [in US prisons]...to be raped by fellow prisoners" (ibid).

Snider reviews knowledge-claims in feminist and nonfeminist criminology on the punishment of women from 1970 to 2000. She argues that the knowledge claims of critical and feminist criminology are part of the incarceration spiral because the construction of women developed in feminist criminology "have structured the ways in which punishment descends upon them" (ibid, p. 355). She includes an interrogation of feminism as possibly complicit in excessive punishment, which is certainly problematic, because feminism's “quest was always to liberate women from oppression not merely analyze it" (ibid). Snider asks: "To what degree is feminist knowledge...a component in surging levels of punitiveness" towards women (ibid)?

While Snider deftly handles a large amount of feminist criminology literature and its critique, she says that to understand the "punishable woman", "scholars must shift analytical attention away from discourses produced and on to those heard, looking beyond deconstruction to political economy" (ibid):

On the positive side, it became clear that feminists in criminology have contributed to the constitution of a self-aware, robust, female offender, equipped with languages and concepts of resistance, on an individual 
(if not collective) level. The female offender is no longer considered "innocent"... However the very success of these claims in the public arena, the constitution of aware, resistant subjects who no longer "know their place," is a central component in the virulent and powerful backlash against all progressive movements, not just feminism, that has swept through western states in the last two decades (ibid, p. 356).

Snider goes on to argue that neo-liberal regimes have rolled back incremental gains by movements to replace amelioration with punishment - the latter becoming the key function of government.

First-wave, feminist reformers sought to "reform" women to save them from harsh prisons: the keepers were well-intentioned, feminist, liberal reformers whose "reformatories" were created to provide alleged nurturing for our society's nurturers - a conflict between domesticity and discipline. These reformatories were primarily for white, working-class women convicted of minor, sex-related offenses. This allowed women to have a voice in public discourse as reformers of the prison system. Female staff were controlled and surveilled as much as prisoners (ibid, pp. 358-359).

Snider's analysis of feminist, criminology literature compared with policy discourse finds two types of criminalized women: the Woman in Trouble of feminist-criminology discourse versus the Female Criminal of policy discourse. The Woman in Trouble (ibid, pp. 364, 367) is poor and "the caregiver, the impoverished, aboriginal and/or victimized woman" (ibid, p. 367). This is the "needy, but not the punishable offender" (ibid, p. 364). Here, she argues, "women's abuse experiences structure their lives and their offending" (ibid) and means women need healing, not incarceration. Thus, Snider calls the criminalized woman as Woman in Trouble: "a woman of entitlement, one whose crimes have to be understood in relation to her victimization (albeit in a manner determined by penal authorities). Because she has been victimized she is a subject who 'deserves' better treatment than she has received. She is entitled to demand more programmes, more healing, less punishment" (ibid, p. 366).

Unfortunately, pointing out difference and need "to guide penal policy in a humane and liberating direction, has been heard through discourses of risk. Thus high need equals high risk equals maximum security confinement for the inmate - in the guise of meeting inmate needs and 'empowering' her" (ibid). 
Snider credits feminism with altering the worldview of female arrestees/ prisoners, and with the fact that criminalized women challenge the claims of "authorized knowers" to create a critical "feedback loop or spiral" where "resistance is now (re)inscribed into patterns of governance" (ibid, p. 367). Victoria Law (2012), herself a former prisoner, is one of the Amnerican feminists who documents the tactics of resistance by female prisoners and helps aid those tactics.

Along with the "Woman in Trouble", Snider finds another "female offender": the Female Criminal. "[T]he predatory, rational, calculating Female Criminal, the violent gang girl, or the irresponsible, out-of-control Bad Mother/Child Abuser" who is "the woman of policy discourse, the woman who justifies the surge of punitiveness reflected in the incarcerations rates" to create an "ever-widening gap between knowledge claims in criminology and official policy" (Snider, 2003, pp. 367-368). This category is the same as Martin's (1999) "bad" criminalized woman.

The statistics compiled on the increase of incarceration of women are staggering. Sharona Coutts and Zoe Greenberg of RH Reality Check (2015) find that the number of women in state and federal prisons in the United States "jumped by 646 percent between 1980 and 2012 - from around 25,000 to more than 200,000-one-and-a-half times the speed at which the incarceration for men increased during the same period" (p. 1).

Snider (2003, p. 369) looks at international data from the 1983-2003 timeframe and finds "the total number of incarcerated males increased 303 percent from 1980-99, it increased 576 percent for females". She also finds that "[b]etween 1986 and 1991, African-American women's incarceration rates for drug offences rose by 828 percent, that of Hispanic women by 328 percent, that of white women by 241 percent" (ibid; also see Chesney-Lind and Faith, 2001, pp. 25-26). Snider (2003, pp. 368-369) comments:

These figures. ... force us to ask why the discourses produced by authorized knowers that legitimate less punitive treatment for female offenders are either not heard (as in many American states) or heard in ways that authorize expanded surveillance, repression, and control (as in Canada and Australia). ... Part of the answer lies in the triumph of discourses of equality, and the apparent determination of some policy makers and officials to use this idea, this set of knowledge claims, to bring women (back) into line, to ensure that female offenders, in particular, do not 'get away with anything'. 
Some of the effects of liberal, feminist-inspired, "equal treatment laws", according to Snider, "destroyed 'early' parole, and authorized women's inclusion on chain gangs" (ibid).

New laws on spousal assault worldwide have seen women charged for defending themselves and others charged with contempt of court for their unwillingness to testify against their partners (Snider, 1994, 1998). Meda Chesney-Lind (2002, p. 82) found that pro-arrest policies in the United States, for example, have led to "mutual" arrests (the practice of arresting both the man and the woman in a domestic violence incident if it is not clear who was "primary" aggressor), and that nearly 90 percent of the increase in the number of violent female felons was accounted for by aggravated assaults, likely from increased prosecution of women in battering cases (ibid, p. 85). Between 1990 and 1996 the number of convicted female defendants grew at 2.5 times the minimum rate of increase. Chesney-Lind has a conclusion similar to Kilty and Frigon: "If 'abuse' is decontextualized, if the motive of the violence cannot be considered, and if the meaning of the 'violent' behavior is irrelevant, then we will arrest girls and women" (ibid, p. 86).

Unfortunately, Snider (2003, p. 369) has to conclude that: "[I]n a culture of punitiveness, reforms will be heard in ways that reinforce rather than challenge dominant cultural themes; they will strengthen hegemonic not counter-hegemonic practices and beliefs". She says we must analyze continually power relations in academe and public policy to "understand why and how the claims of one set of authorized knowers (... right, realist criminology) 'grow legs' and hop off the computer screens... on to the legislative agendas of politicians, while [claims of feminist criminology] atrophy and die" (ibid).

Here, I would add that the advocates of male prisoners end up on legislative agendas, versus those advocating for women. The 2013 Texas Legislature passed a bill to legalize sex between adult males and teenage girls, as long as there was no more than a three-year age difference; this bill was flippantly called the "Romeo and Juliet bill". Fortunately, Governor Rick Perry vetoed it.

Martin (1999, p. 188) has three, contradictory, stereotypes of female arrestees as "simply sad", mostly mad" or "basically bad". With the first group, she believes that has found that it may be possible that certain women receive preferential treatment: attractive, young, and middle class. Otherwise, she argues, the myth of "chivalry in sentencing" is exactly that: leniency may 
be more apparent than real "in many cases, the more lenient sentences were quite justified, given the lesser involvement of the woman, or the fact that the crime was less serious than originally described" (ibid, p. 189). The "mostly mad" category is created by a disproportionately high number of women sent to psychiatric institutions due to "the idea that 'normal' women do not commit crimes unless compelled to by a man also reinforced the idea that the women who do commit crimes are 'abnormal'. It is a short step to conclude that they are also "sick"' (ibid, p. 189). I found anecdotally that many of the women in my group, Free Battered Texas Women, were psychiatrized by the police or by their own court-appointed attorneys.

Let me explain with my own personal experience in this area. When I met my first, court-appointed criminal attorney on the cause described herein in February 2004, he refused to listen to anything I had to say about my evidence and innocence. "I want you to talk to this psychiatrist", he said, adding that the DA had claimed that the Sheriff's Office (who runs the jail) claimed I needed a psychiatric evaluation. I reiterated the need for him to acquire the photos of my injuries taken by the jail staff, by the battered-women's shelter, and by a law-student acquaintance, as well as medical records from the assault-exam conducted by a local hospital that the shelter had sent me to. He refused. I told him I wanted him off my case. A client's desire to have her attorney removed creates an inherent conflict-of-interest under Sixth Amendment case law, the provision of the United States Constitution that mandates effective assistance of counsel for criminal defendants.

This attorney refused to withdraw. Then he wrote to threaten that he would have me declared incompetent if I did not agree to his strategy. I filed motions to dismiss this attorney with my three judges in the felony, misdemeanour and protective-order courts. Somehow, the hearing was held only in the misdemeanour court by a judge who denied my request and then found me incompetent at a later hearing. When the other two judges heard my dismissal motion in person for the first time five weeks later, they quickly fired this attorney. However, that was after weeks of suffering daily tackling and forcible injection of a drug that knocked me out because this attorney wanted to control me due to misogynist brainwashing by a DA who did not have a case. What's my proof? The DA did not go to a grand jury for an indictment until after my own attorney had me declared incompetent - this was one of the factors coercing me into a plea bargain. At that plea setting, the DA had me plead to a nonviolent, criminal-trespass 
misdemeanour that I also was innocent of - showing that they knew I had not committed violence and saying: "We weren't exactly sure she entered with intent to commit assault". I lost two and a half months on my case while I was being tortured in the so-called state hospital. It was only after the lawyers from Advocacy Incorporated (now Disability Rights Texas) intervened that I was released.

Other battered women I met in the Travis County Jail were also psychiatrized by jail staff and their own attorneys to violate their bodies and presumption of innocence. Rhonda Glover told me she had repeatedly called the Austin police to report her boyfriend beating her and molesting her son to no avail. When he finally pulled a gun on her in the middle of a beating, she wrestled it away from him and shot him to death in lawful selfdefense. Yet her attorney had her declared incompetent and sent hundreds of miles away to the Vernon State "Hospital" along the Oklahoma Border. HS was in her 50s and an MBA-holding ranch-owner when I met her in Spring 2005 in the jail. Her much-larger husband had gotten drunk and beat her. She shot at him - nicking his neck so he only required a Band-Aid. This distracted him enough for her to leave. When she went to the police, they photographed her injuries, yet charged her with aggravated assault. The jail staff injected her with Thorazine so she slept for a couple of days and could not call her attorneys to begin her defense.

The third category Martin (1999) presents, that of the "inherently bad" criminalized woman that the courts justify punishing harshly, is the woman accused of committing a violent offense. She is seen as "more deadly than a male" because "violence is seen as contrary to [women's]... 'proper' role as gentle victim" (ibid, p. 190). It is this category that those of us who defended ourselves against our batterers (or defended children or grandchildren) are placed into and the reality of our victimhood is erased to do so. As Merrie Lehning, who is serving a 52-year sentence in Texas for killing her batterer in self-defense, told me: "These people [in the justice system] are trying to erase our pasts and destroy our futures".

\section{WOMEN AND SELF-DEFENSE}

The National Clearinghouse for the Defense of Battered Women (NCDBW) (2011) cites statistics from the FBI, Crime in the United States 1995: Uniform Crime Reports, showing that female homicide victims are more than twice as likely to be killed by husbands or boyfriends than the male victims are to 
be killed by wives or girlfriends (also see Craven, 1996). Ninety percent of female homicide victims in the United States are killed by men, most often by a family member, spouse or ex-partner. Approximately 70 percent of murdered women are killed by a current or estranged husband or lover in the United States (also see Campbell, 1995). Based on the data from the FBI's Supplemental Homicide Report, in 2007, 64 percent of female homicide cases were committed by a family member or intimate partner. Specifically, 24 percent of female homicide victims were killed by a spouse or ex-partner, 21 percent were killed by a boyfriend or girlfriend, and 19 percent were killed by another family member (that does not include ex-boyfriends).

The NCDBW (2007) statistics on sentencing show that the proportion of female prisoners convicted of violence against intimates who received life terms or the death penalty (33 percent) is higher than for male prisoners convicted of violence against intimates (19 percent). The difference is probably attributable to the higher proportion of female prisoners being convicted of some form of homicide of an intimate (also see Zawitz, 1994). In a review published in 1987 of 100 battered women charged with killing their batterers, nine women pleaded guilty to murder, manslaughter, or criminally-negligent homicide and were given sentences ranging from conditional discharge or probation to 20 years in prison, three entered pleas of not guilty by reason of insanity and were acquitted, and three had the charges against them dropped before trial. The remaining 85 women went to trial on homicide charges, claiming self-defense. Twenty-two were acquitted and the 63 others were convicted of various forms of criminal homicide. Twelve of those women, all convicted of murder, received sentences of life in prison, one without parole for 50 years (also see Ewing, 1987). It is easy to see why someone would take a plea bargain for a lesser sentence, despite innocence.

The California Coalition for Women Prisoners (CCWP) (2014) reports that nearly all ( 80 percent) of the women in California's prisons have experienced some form of abuse during childhood or as adults. Over half (60 percent) reported physical abuse as an adult, primarily perpetrated by spouses or partners. Of the 45 women on death row in 1993, almost half (approximately 49 percent) had a history of abuse and were there for killing an abusive spouse or lover. Out of the 223 reviewed appellate opinions of cases where battered women kill their abusers, 75 percent involved confrontations, meaning the woman was being assaulted or abused at the time of the killing. Threats of physical injury, mutilation or death were common among a study of 100 battered women who killed their batterers 
between the years of 1978 and 1986. In 41 cases, it was reported that the batterer had threatened to kill the woman at some point in the relationship and 39 women had been threatened or assaulted at least once with a weapon.

As for once these women are arrested and in the justice system, the CCWP find that battered women who kill are either being convicted or taking pleas at a rate between 72 percent and 78 percent nationally. Significantly, CCWP finds that women usually kill men, not women, and women charged with homicide had the least-extensive prior criminal records of any people convicted of crimes. CCWP states that several hundred women in California are serving time for killing their batterers. Hundreds, if not thousands, more are serving time for domestic-violence-related crimes. CCWP shows that battered women who petition for parole are often ignored by the governor. Of those 34 incarcerated battered-women who were assisted by CCWP in 1992 with parole petitions, 24 never received a response.

The Texas Criminal Justice Coalition (2015) mailed surveys to women being held in the Texas Department of Criminal Justice. 421 women submitted completed surveys for review. The majority of these women were white ( 49.3 percent) and more than 50 percent of them had household incomes of less than $\$ 10,000$ per year before being incarcerated. The majority were unemployed (47.4 percent) and 35.2 percent had less than a high school degree. Of the 57.4 percent of the women that were abused as a child, 30 percent said they were five years or younger the first time. Those responding to the survey also reported that 62.6 percent of them were physically abused as adults, and only 44.6 percent reported this abuse. These women also reported that 47.5 percent of them said they were sexually abused as an adult, with only 27.4 percent reporting their abuse to the authorities. The survey reports that 82.1 percent of them considered themselves domestic violence victims; and 47.4 percent of them witnessed their mother being battered. Comparable data on plea bargains, parole and the like for incarcerated battered women in Texas is not available.

I have already briefly summarized that the Austin police found my battering ex and/or his friend on top of me hurting me in two separate incidents in 2004 and that they arrest the battered woman instead of the male batterer at least 20 percent of the time on "domestic violence" calls in Texas, according to the Texas Council on Family Violence (2010; 2011; 2014a; 2014b). During the first incident, my ex had shoved my face into the sofa to smother me and I do not know how I am still alive - he completely overpowered me. He then wrapped his arm around my neck in a chokehold. That is when I bit him in 
self-defense, which is permissible in Texas if "the actor reasonably believes the conduct is immediately necessary to avoid imminent harm" (TEXAS PENAL CODE, Subchapter C, SECT. 9.22.). If I had not bit him, I would be dead. Yet the State characterizes that one bite as "violent", while lying that my ex's 90-minute beating and murder attempt are self-defense - victim-blaming by the State as Big Boy, à la hooks. The beating that followed included him sitting on me after he had taken the phone from me and him hanging up when I screamed for help as the 911 operator answered. The police did not respond. He knelt on my calf to pin me and pounded my back with his fists. When I stood, he grabbed me from behind and I attempted to throw him off. He fell on top of me and bashed my face into the floor. Then he dragged me outside and got his friend to join in.

Self-defense waivers have been the subject of scrutiny in the United States following the killings of multiple, African-American males by nonblack males. MBA-educated Marissa Alexander, an African-American woman, had separated from her batterer, Rico Grey. Yet he broke into the house to strangle and beat her. She broke free to escape out of the garage, but the door would not open. She grabbed her gun and fired into the ceiling, injuring no one. Yet she was the one arrested with aggravated assault. The court would not allow her to use a self-defense argument regarding her shot into the ceiling to scare off her husband, who was a "convicted womanbeater," according to Annaliza Torres (2014), Victoria Law (2013) and Aliyah Frumin (2014). The court sentenced her to 20 years for aggravated assault when the bullet did not hit him. As supporter Sumayya Coleman observes, "If you get 20 years for defending yourself, what does that say to victims? Let them beat you, your life means nothing" (Slater, 2013).

Alexander's conviction was overturned in 2013. At that time, her prosecutor, Angela Corey, vowed to retry Alexander and get her sentenced to three, consecutive sentences for 60 years! Despite national outrage, Corey was not stopped. The federal government did not step in. Frumin (2014) writes that in November 2014, Alexander pled out to three, trumped-up, felony charges, and the judge sentenced her to three years in prison. As Alexander had already served 1,030 days on the first case, she was released 27 January 2015. Alexander is being denied the protection of the very "Stand Your Ground" laws that the notorious George Zimmerman used to successful acquit himself in his shooting death of black, male, teenager Trayvon Martin.

My felony prosecutor did a "Motion in Limine" in my criminal trial to bar me from discussing my ex's battering history, when exculpatory 
material cannot be barred in a criminal trial. Without that exculpatory material, I could not put forth a self-defense argument. So, the prosecutor felt she could lie with impunity, while my own attorney was barred from saying I defended myself in the criminal proceeding, even if he had been interested in doing so. I say the latter because he did finally present 28 photos of my injuries in the punishment phase and put me on the stand, but mischaracterized them as my idea of a "catharsis", and he referred to the beating I suffered as a "scuffle". Both the felony and the civil prosecutor (on a protective order) reduced themselves to the same "Othering" strategies my batterer used: calling me a "liar" and "crazy". My own research on sexual harassers found that those who rape and batter employ four strategies when confronted with their misconduct: 1) they lie; 2) they deny; 3) they blame the victim (say she deserved it); and 4) they call the victim "crazy" (Marston, 1993). That is not what public servants sworn to promote justice are supposed to do!

I filed for the transcripts, photos, and other evidence from the civil, protective order proceeding in a timely manner, but they were never provided. I was denied a right to appeal that false order, which was used to construct the felony charges used to imprison me. The DA claimed at the felony trial in May 2005 that the protective order proved I had committed family violence before, when all it proved is that the police, prosecutors, court-appointed attorneys, and judges in Austin and Travis County related to that case were interested in promoting lies and empowering my batterer, along with his friend.

It is no surprise, therefore, that the same 28 photos of my injuries used in my civil case and misrepresented and minimalized by my attorney in my criminal case were gone from my criminal record - as were exculpatory emails - when I finally had the money to pay to replace the free copy that prison guards stole from me in 2006. It is a felony to tamper with evidence in Texas and it is a misdemeanour to refuse to produce public records. I need $\$ 25,000$ to pay my attorney to write a writ of habeas corpus - I do not have the money.

While I have talked about self-defense, please note that Texas also has a "Defense of Third Party" waiver that many women are arrested under for defending children or grandchildren against imminent harm from batterers/rapists, namely Texas Penal Code, Subchapter C, sect. 9.33. Statistics I have taken of all the battered women I have encountered incarcerated since 2005 to October 2015 on domestic violence-related 
cases who report that they defended themselves and/or their children and/ or grandchildren show that 77 percent defended themselves, 15 percent defended a third party, and 8 percent did both.

In a book released in 2013, University of Ottawa Law Professor Elizabeth Sheehy says that battered women are "morally entitled" to kill our abusers and compares battering survivors to prisoners of war as "[w] e would never say of a prisoner of war that it's not just that she or he kill their captor to escape. ... We should say you were right to kill to save your own life". Sheehy goes on to say, "[w] hen women kill to save their own lives, they assert that they matter, that their lives count" (Butler, 2013). Janice Kennedy (2013, p. B7) says that this complex moral position is not handled well in headlines, nor by those who "can't conceive of self-defence as anything more complicated than an immediate reaction to imminent danger". Kennedy lauds Sheehy for an exhaustive study with the goal of reforming "the countless ways our criminal justice system fails abused women and our social safety networks fail to find them safe exits" (ibid).

Molly Redden (2015, p. 32) reports that innocence projects "have tended to avoid cases in which the offender knew the victim, because it can be hard to untangle what happened in a domestic crime". However, she also knows that when women kill, they usually kill someone close to them. The innocence projects operate primarily by reviewing DNA evidence, which is not relevant in battering cases. Karen Daniel and Judy Royal of the Center on Wrongful Convictions at Northwestern University Law School found that in 63 percent of cases where women were convicted, there was never a crime to begin with (ibid). They also found that 37 percent of exonerated women were convicted using false or misleading forensic evidence (ibid, p. 33).

Ms. magazine reported in its Winter/Spring 2014 issue (p. 25) that Italy's prime minister enacted a 12-point decree to end battering, which is that country's top killer and injurer of women. Feminist activists there said what is primarily needed is enforcement of existing laws - the same arguments I make about ending wrongful arrest of battered women here in Texas. I believe that male violence against women is an operating ideology that needs to be stopped at its roots in boyhood.

Pamela Colloff $(2014$, p. 24) has covered the Texas criminal justice system for Texas Monthly. She writes that it is high time for prosecutors to be punished for their role in what she calls the common theme between all the cases she has covered, as "the prosecutors who sought their indictments and secured their convictions should never have tried the cases in the first 
place". I was introduced to Colloff's work when she wrote about my unitmate Hannah Overton, who was convicted for the death of her foster son, who was later revealed to have a medical condition called pica. Colloff characterizes Overton's DA as "aggressively" pursuing a "life without parole" sentence for Overton, "even though it could not answer the most basic questions about how she would have committed the crime" as someone who was six months pregnant and bedridden from a car accident. The Texas Court of Criminal Appeals overturned Overton's conviction in September 2014, but on the grounds she had ineffective assistance of counsel. It refused to deal with the issue of malicious prosecution, merely because it had granted relief on her first ground.

Colloff's focus is on how Overton's case and many others involve the prosecutor withholding exculpatory evidence from the defense. In Overton's case, there was a sample of the victim's vomit from earlier in the day. In Michael Morton's case, there was a blood-stained bandanna with the DNA of the man who really killed his wife; yet his attorneys did not know about it and Morton did more than 20 years in prison until his exoneration in 2012 or so. Anthony Graves was sent to death row in 1994 for killing six people, but was exonerated after it was revealed that the real killer had implicated himself, but was pressured by prosecutors to name a co-conspirator.

In 2013, the Texas Legislature passed the Michael Morton Act requiring prosecutors to share both incriminating and exculpatory evidence with the defense before going to trial (Colloff, 2014, p. 90). This is certainly a start. However, Colloff rightly points out that there is more to be done:

...the State Bar of Texas needs to radically reform the way it handles allegations of prosecutorial misconduct; right now the Bar's guiding principle seems to be to ignore even the most egregious examples of behavior by prosecutors unless there is enough attendant media attention that some sort of action must be taken-and even then, it's usually a slap on the wrist (ibid, p. 30).

She goes on to cite a study done of the Texas Bar by the California Innocence Project, which found that in 91 criminal cases in Texas in which the courts decided there had been prosecutorial misconduct, the Bar failed to discipline anyone. In one case, the prosecutor and judge were romantically involved, and it led to a death sentence for the defendant. They were never disciplined. Christopher Zoukis (2014) also discusses prosecutorial misconduct 
nationwide. It is rampant, partly because there is no uniform, reporting body.

I never filed a complaint against a prosecutor to the Bar. However, I did grieve an old boyfriend who wrote to me in prison to whine how he had left prosecuting to become a defense attorney because of a case in which he falsely prosecuted a woman in the accidental death of her husband. He was successful and his judge apparently told him "It takes a hell of a prosecutor to convict an innocent person". I have also grieved my defense attorneys to the Bar - especially when the judge in my criminal case fired my trial attorney, then appointed the trial attorney's brother on my appeal. The Bar did nothing.

Colloff (2014) argues that the Legislature needs to do away with absolute immunity for prosecutors, downgrading it to qualified immunity - the same protection provided for police officers, which allows for civil suits. Such legislation would help to "counterbalance the pressure prosecutors feel to rack up convictions and never admit mistakes" (ibid, p. 32).

Olivia Lord was no-billed by a grand jury in Texas in the death of her boyfriend - meaning that the grand jury refused to indict her. It was clear later that he was suicidal and waiving his gun drunkenly earlier in the evening in front of his friends. Lord sued the detective who aggressively sought to falsely charge her. The civil court granted her millions in monetary damages, but an internal affairs investigation by that detective's police department found no wrongdoing (Hollandsworth, 2014).

What is really needed in Texas is legislation similar to that passed in California - their "Sin by Silence" bills, AB 593 and AB 1593 - and up for consideration by the New York legislature (Domestic Violence Survivors' Justice Act), which would give wrongfully-arrested women ways at various stages of the legal process to have their status and experiences as battering survivors contextualized against the alleged, domestic-violence-related offense (Law, 2013). California's AB 593 has a statute to allow incarcerated women to cite intimate-partner battering (IPB) as a ground for overturning their conviction on a writ of habeas corpus. The battering committed against women would be taken into consideration in parole, as well, via AB 1593. This legislation also assures that when female prisoners tell the parole board that their crimes are related to being battering survivors, the board cannot penalize them for "lack of insight". The New York bill would take into consideration if someone is a defendant who, at the time of their offense, was subjected to domestic violence: physical, sexual or psychological abuse inflicted by a family member or member of the same household. 
However, my concern for this legislation is that it does not go far enough in providing reviews by state innocence projects and other legal non-profits. The Texas Innocence Project, for example, does not seem to recognize that self-defense and defense-of-a-third-party constitute "actual innocence" worthy of their attention. Again, as Redden (2015) found above, the Innocence Project has been DNA testing to exonerate convicted rapists for decades, while refusing to review battered women's cases.

As I write this in Fall 2015, I am researching these laws and the 1991 Senate Combined Resolution (SCR) 26 that created the Texas Council on Family Violence and gave it power only to recommend battered women for pardons - with the pardoning power still held by TDCJ's Board of Pardons $\&$ Paroles. My recommendations to the legislature:

1. Stopping wrongful arrest of battered women via legislation that stresses adherence to the state's pre-existing self-defense and defense-of-third-party waivers. This may include the creation of review bodies at the city, county and state levels of each arrest of women on a domestic-violence charge.

2. Exonerating battered women already in prison or who have served their sentence. This legislation would direct our state's innocence projects and other legal entities (nonprofits, law schools, etc.) to review convictions in this area of law, as women who defended themselves or a third-party are erroneously not considered "actually innocent" via current misinterpretations of our pre-existing statutes.

3. Addressing other arrests and convictions for non-domesticviolence-related offenses that are actually mitigated by battering. For example, a woman who is being battered by a man might assent to running drugs for him.

\section{FURTHER STUDY}

On 11 February 2015, I spoke to members of the Texas Legislature as part of a lobby day sponsored by The Texas Council on Family Violence and Texas Association against Sexual Assault. The message was "Love shouldn't hurt". On 14 February 2015, Valentine's Day, the movie "50 Shades of Gray" opened in theaters across the United States to much media 
coverage - sending the opposite message and encouraging women to think of battering as love worthy of commitment.

Feminist, media scholar Meyers (1994) studied news coverage of the murders of battered women by their male, significant others and found that this coverage blamed the dead, female victims. It took me 10 years to get something published in the mainstream press on the topic of wrongful arrest of battered women - I had to add two co-authors and limit myself to 600 words, yet the editor cut a co-author's byline and part of our text (see Castillo and Marston, 2014, for what got published by the San Antonio Express-News; for our full critique, see Castillo et al., 2014). Clearly, the ways that the media cover male violence in the criminal justice system needs to be interrogated and remedied.

\section{ENDNOTES}

1 An earlier version of this paper was presented at the Fifteenth International Conference on Penal Abolition in Ottawa, Ontario, Canada. I would like to thank the anonymous reviewers for their suggestions, as well as Justin Piché and Jennifer Kilty of the University of Ottawa, Mechthild Nagel of SUNY-Cortland, Bill Christ and Meredith Elsik at Trinity University, and Gabrielle Pilliat who keyed in my manuscript to accommodate my hand disabilities. I also thank Sarah Pahl, Policy Attorney of the Texas Criminal Justice Coalition, for the preliminary survey data on incarcerated women, Jorge Renaud for three years of support of my case and this cause, as well as for facilitating communication with TCJC, Sue Ostoff, Executive Director of the National Clearinghouse for the Defense of Battered Women, for their packets on intimate partner homicide and sentencing, and Diana Block and Pamela Fadem of the California Coalition for Women Prisoners for their statistics on sentencing and parole of women convicted in intimate-partner homicide. Lastly, I thank Jaya Vasadani and Tamar Kraft-Stolar of the Correctional Association of New York for information on New York's Domestic Violence Survivors' Justice Act, as well as Victoria Law for helping us connect, as well as for her research and blog.

2 This is not to criticize the fine work of Michael Lenza, whose "autoethnographic" work I enjoy immensely, as well as his consistent efforts to include critical, race theory and feminism into his analyses. We have different intellectual starting places.

3 An interview on NPR's "Here and Now" the week of 11 January 2015 with an author of a book on handling trauma also agrees that it is not a disorder or pathology to be afraid and mistrust authority, have nightmares and the like. 


\section{REFERENCES}

Associated Press (2012) "Ex-cop soon to be in headlines again", San Antonio Express News, A12 - July 22.

Atkins, Dawn and Cathy Marston (1999) "Creating Accessible Queer Community: Intersections and Fractures with Dis/ability Praxis", Journal of Gay, Lesbian, \& Bisexual Identity, 4(1): 3-21.

Behar, Ruth and Deborah Gordon (1995) Women Writing Culture, Berkeley: University of California Press.

Bell, Diane (1993) "Yes Virginia, There is a Feminist Ethnography: Reflections from Three Australian Fields", in Diane Bell, Pat Caplan and Wazir Jahan Karin (eds.), Gendered Fields: Women and Men in Ethnography, London: Routledge, pp. 28-43.

Bird, S. Elizabeth (1987) "Anthropological Methods Relevant for Journalists", Journalism Educator, 41(4): 5-10, 33.

Butler, Don (2013) "Battered women morally entitled to kill abusers, U of O professor asserts", Ottawa Citizen - December 10.

California Coalition for Women Prisoners (2014) "Fact Sheet: Statistics on Parole and Battered Women", California Coalition for Women Prisoners. Retrieved from http:// www.womenprisoners.org.

Campbell, Jacqueline C. (1995) "Prediction of Homicide of and by Battered Women", in Assessing Dangerousness: Potential for Further Violence of Sexual Offenders, Batterers, and Child Abusers, Thousand Oaks (CA): Sage, pp. 97-98.

Capitan, Craig (2012) "Cornyn praises bill to increase money for tests of rape cases", San Antonio Express-News, B4 - May 6.

Chesney-Lind, Meda (2002) "Criminalizing Victimization: The Unintended Consequences of Pro-arrest Policies for Girls and Women", Criminology and Public Policy, 2(1): 81-90.

Chesney-Lind, Meda (1988) “Girls and Status Offenses: Is Juvenile Justice Still Sexist?", Criminal Justice Abstracts, 20: 145-65.

Chesney-Lind, Meda (1987) "Girls and Violence: An Exploration of the Gender Gap in Serious Delinquent Behavior", in D. Corwell, I. Evans and C. O'Donnell (eds.), Childhood Aggression and Violence, New York: Plenum, pp. 207-230.

Chesney-Lind, Meda (1981) "Juvenile Delinquency: The Sexualization of Female Crime", Psychology Today, July: 43-46.

Chesney-Lind, Meda and Karlene Faith (2001) "What About Feminism? Engendering Theory-making in Criminology", in Raymond Paternoster and Ronet Bachman (eds.), Criminological Theories, Los Angeles: Roxbury Press, pp. 287-302.

Clifford, James and George E. Marcus (1986) Writing Culture: The Politics and Poetics of Ethnography, Berkeley: University of California Press.

Clark, Jeanne K. (2007) 'Police beat', Ms., 17(4): 14-15.

Collins, Patricia Hill (1986) "Learning From the Outsider Within: The Sociological Significance of Black, Feminist Thought", Social Problems, 33(6): 14-32.

Colloff, Pamela (2014) "The guilty and the innocent: the case for punishing prosecutors who abuse their power", Texas Monthly, 42(11): 24-32. 
Coutts, Sharona and Zoe Greenberg (2015) "Women, Incarcerated", Prison Legal News, 26(6): 1, 3-16.

Craven, D. (1996) Female Victims of Violent Crime, Washington (D.C.): Bureau of Justice Statistics.

Ewing, C.P. (1987) Battered Women Who Kill, Lexington (MA): Lexington Books.

Faludi, Susan (1991) Backlash: The Undeclared War Against American Women, New York: Crown.

Frumlin, Aliyah (2014) "Melissa Alexander accepts plea deal", MSNBC - November 24. Retrieved from http://www.msnbc.com/msnbc/marissa-alexander-accepts-plea-deal.

Hallett, Stephanie (2011) "How to stop a serial rapist", Ms., XXI(3): 32-35.

Harding, Sandra (1987) Feminism and Methodology: Social Science Issues, Bloomington: Indiana University Press.

Hollingsworth, Skip (2014) "A shooting on Spring Grove Avenue", Texas Monthly, 42(11): 112-115, 170-182, 204-206.

hooks, bell (2000) All About Love: New Visions, New York: William Morrow \& Co.

Horvath-Neimeyer, Paula S. (1990) "Journalism and Anthropology: Creation of Cultural Curriculum”, Journalism Educator, 44(4): 31-38.

Jones, Ann (2003) “Battering: Who’s Going To Stop It?”, in Lily Kesselman, D. McNair and Nancy Schneiderwind (eds.), Women: Images and Reality - A Multicultural Anthology, New York: McGraw-Hill, pp. 449-454.

Kennedy, Janice (2013) "Not a license to kill; Elizabeth Sheehy's examination of the battered woman defence is more nuanced than many of her critics acknowledge", Ottawa Citizen, B7 - December 28.

Kilty, Jennifer and Sylvie Frigon (2006) "Karla Homolka -- From a Woman in Danger to a Dangerous Woman: Chronicling the Shifts", Women \& Criminal Justice, 17(4): 37-61.

Kruttschnitt, Candace (1981) "Social Status and Sentences of Female Offenders", Law and Society Review, 15(2): 247-65.

Law, Victoria (2013) "Trapped in the dark: Marissa Alexander and how our twisted legal system re-victimizes domestic-violence survivors", Salon. Retrieved from http:// www.salon.com/2014/05/16/trapped_in_the_dark_marissa_alexander_and_how_ our twisted legal system re victimizes domestic violence survivors/.

Law, Victoria (2012) Resistance Behind Bars: The Struggles of Incarcerated Women (second edition), Oakland: PM Press.

LeGates, Marlene (1995) "Feminists Before Feminism: Origins and Varieties of Women's Protest in Europe and North America Before the Twentieth Century", in J. Freeman (ed.), Woman: A Feminist Perspective, Mountain View (CA): Mayfield.

MacKinnon, Catherine (1989) Toward a Feminist Theory of the State, Cambridge (MA): Harvard University Press.

MacKinnon, Catherine (1983) "Feminism, Marxism, Method, and the State: Towards a Feminist Jurisprudence", Signs, 8(4): 635-658.

Mairs, Nancy (1996) Waist-high in the World, Boston: Beacon Press.

Mairs, Nancy (1990) Carnal Acts, New York: Harper Collins.

Marston, Cathy (2014a) "Defending our right to self-defense to counter the normalization of violence", La Voz de Esperanza, 27(8): 3-4, 6.

Marston, Cathy (2014b) “Texas Families for Justice rally”, La Voz de Esperanza, 27(10): 12. 
Marston, Cathy (2011) "Stopping the Real 'Cycle of Violence': Patriarchal Battering and the Criminalization of Women by American Police and Prosecutors", Journal of Prisoners on Prisons, 20(1): 72-83.

Marston, Cathy (2000) Damaging Lessons: The Disabling Environment of College Newsworkers From a Feminist Ethnographic Perspective, unpublished doctoral thesis, University of Iowa.

Marston, Cathy (1999) "Learning to be a Journalist: A Feminist, Disability Critique of Cyborgs, College Newsworkers, and RSI Work Culture", Journal of Communication Inquiry, 23(3): 266-287.

Marston, Cathy (1998) "Learning to be a Journalist: A Feminist, Disability Critique of Cyborgs, College Newsworkers, and RSI Work Culture", paper presented to the Association for Education in Journalism \& Mass Communication Annual Conference in Baltimore - August.

Marston, Cathy (1996) "Feminist Ethnography and Rethinking Sources: Toward Feminist Reporting", paper presented to the Organization for the Study of Communication, Language and Gender's Annual Conference, Monterey (CA) - October 5.

Marston, Cathy (1993) Sexual Harassment and Social Control in the Newsroom: Women's Narratives, unpublished master's thesis, University of Texas at Austin.

Martin, Dianne (1999) "Punishing Female Offenders and Perpetuating Gender Stereotypes", in David P. Cole and Julian V. Roberts (eds.), Making Sense of Sentencing, Toronto: University of Toronto Press.

Meyers, Marian (1994) "News of Battering", Journal of Communication, 44(2): 47-63.

Nagel, Mechthild (2013) "Patriarchal Ideologies and Women's Domestication", in Mechthild Nagel and Anthony Nocella (eds.), The End of Prisons: Reflections From the Decarceration Movement, Amsterdam: Rodopi, pp. 147-167.

National Clearinghouse for the Defense of Battered Women (2011) Intimate Partner Homicide Statistics Packet, Philadelphia.

National Clearinghouse for the Defense of Battered Women (2007) Sentencing Statistics Packet, Philadelphia.

Pascarelli, Emil and Deborah Quilter (1994) Repetitive Strain Injury: A Computer User's Guide, New York: John Wiley \& Sons.

Pence, Ellen, Laura Connelly and Melissa Scaia (2011) Turning Points: A Nonviolence Program for Women, Grand Rapids (MN).

Redden, Molly (2015) "The Innocence Gap: How Many Women Are Behind Bars for Crimes They Didn't Commit?", Mother Jones, 40(1): 30-33, 60.

Savage, Candace (2000) Witch: The Wild Ride From Wicked to Wicca, Vancouver: Greystone.

Shore, Zachary (2008) Blunder, New York: Bloomsbury.

Slater, Anne (2012) "Growing Campaign to Free Abuse Survivor Marissa Alexander Turns Outrage Into Action", Freedom Socialist, 35(1): 6.

Snider, Laureen (2003) “Constituting the Punishable Woman: Atavistic Man Incarcerates Postmodern Woman”, British Journal of Criminology, 43(2): 354-378.

Spohn, Cassie, John Gruhl and Susan Welch (1987) "The Impact of the Ethnicity and Gender of Defendants on the Decision Dismiss Felony Charges", Criminology, 25: 175-91.

Steinem, Gloria (2014) “Our revolution has just begun”, Ms., 331(1): 26-31. 
Texas Criminal Justice Coalition (2015) Survey of Incarcerated Women: Preliminary Findings, unpublished.

Thompson, Natalia (2012) “A review of Margarita Pisano's 'El triunfo de la masculinidad",, La Voz de Esperanza, 25(6): 7-9.

Thomson, Rosemarie G. (1997) Extraordinary Bodies: Figuring Disability Into American Culture, New York: Columbia University Press.

Torres, Annaliza (2014) "Marissa Alexander Out of Jail But Not Free", Freedom Socialist, 35(1): 6.

Tuchman, Gaye (1991) "Media Institutions: Qualitative Methods in the Study of the News", in Nicholas W. Jankowski and Klaus Bruhn Jensen (eds.), A Handbook of Qualitative Research Methodologies for Mass Communication Research, New York: Routledge, pp. 79-92.

Wendell, Susan (1996) The Rejected Body: Feminist Philosophical Reflections on Disability, New York: Routledge.

Wendell, Susan (1989) "Toward a Feminist Theory of Disability", Hypatia, 4(2): 10424.

Williams, Wendy (1997) "The Equality Crisis: Some Reflections on Culture, Courts, and Feminism", in Linda Nicholson (ed.), The Second Wave Reader: A Reader in Feminist Theory, New York: Routledge.

Wolf, Margery (1992) A Thrice Told Tale: Feminism, Postmodernism, and Ethnographic Responsibility, Stanford: Stanford University Press.

Zawitz, M. (1994) Domestic Violence: Violence Between Intimates, Washington (D.C.): Bureau of Justice Statistics.

Zoukis, Christopher (2014) "Prosecutorial Misconduct: Taking the Justice Out of Criminal Justice”, Prison Legal News, 25 (11): 1-22.

\section{ABOUT THE AUTHOR}

Cathy Marston, $P h D$ is Founder and Director of Free Battered Texas Women and was on the Steering Committee for the Fifteenth International Conference on Penal Abolition. She is compiling an anthology of the stories of wrongfully-incarcerated women who defended themselves and/or their kids/grandkids, as well as stories of advocates for these women. She can be reached by email at cmarston.fbtw@gmail.com or by mail at the following address:

Cathy Marston

P.O. Box 47

Schertz, Texas 78154

USA 